\title{
An Analysis of the Equity of Students' Investment Base on Korea Local Education Finance
}

\author{
Jiang Jialei ${ }^{1}$, Eun-Mi, Park ${ }^{2 *}$ \\ ${ }^{1}$ School of Management, Xuzhou University of Technology, Xuzhou, Jiangsu, 221018, China \\ ${ }^{2}$ School of Business Administration, Kyungpook National University, Daegu, 41566, South Korea
}

\begin{abstract}
Background/Objectives: This study analyzes the equity of the per capita investment scale of students in Korea. Methods/Statistical analysis: This study compares and analyzes the equity of the per capita investment of students, the per capita labor cost investment of students and the per capita facility investment of students. In addition, this paper analyzes the changes of students' per capita investment in each year (2011-2014), and evaluates the fairness of students' per capita labor cost and facility cost investment. Findings: The results of this study are as follows. First, on the whole, the per capita investment of students in the city, the road and the land department is relatively fair. The per capita investment of students in different regions of the Municipal Department of education was unequal from 2012 to 2014. Second, according to different regions, the fairness of investment in labor cost and facility cost per student is different. It can be seen that the investment amount of labor cost per student is fair among city, road and land departments. From 2011 to 2014, the labor cost per capita of Gini city showed a rising trend. Third, according to the different districts of the city and the road Education Department, there are differences in the investment amount of labor cost per student and the investment amount of facility cost per student. From 2011 to 2013, Busan city has the largest per capita investment, and Seoul special city has the lowest. Improvements/Applications: After the diagnosis of the fairness of the current investment amount of students among regions, the reasonable improvement plan of education finance is provided to the relatively low areas, and the direction of the distribution and development of student education finance in the future is put forward.
\end{abstract}

\section{Index Terms}

Equity of Students' Investment, Korea Local Education Finance, Education Finance, Education

\section{Corresponding author : Eun-Mi, Park}

issack38317@naver.com

- Manuscript received January 2, 2021.

- Revised January 30, 2021; Accepted February 16, 2021.

- Date of publication March 31, 2020.

(C) The Academic Society of Convergence Science Inc.

2546-1583 @ 2017 IJEMR. Personal use is permitted, but republication/redistribution requires IJEMR permission. 


\section{INTRODUCTION}

One of the important factors in carrying out educational activities is education finance. Education finance is to meet the educational needs of the state and society, provide necessary means and manage its economic activities. Educational finance, like other properties, has the degree to which individual requirements are met.

In Constitution of South Korea 31, paragraph 1, of the constitution, "all citizens have the right to education on the basis of equal ability" and "all citizens have gender, religion, belief, social status" in Constitution of South Korea 4 of the basic law of education The provision of "non discrimination in education" emphasizes equal opportunities for education on the basis of economic status or physical conditions. Fair investment in education cost is necessary for providing equal education services for the education demanders.

The issue of fair distribution and guarantee of educational finance is related to equal educational opportunities. Even if education finance is fairly guaranteed and distributed, if its scale is not enough to carry out students' educational activities, it is difficult to guarantee educational opportunities.

From this point of view, the equity of education finance is closely related to the equality of students' educational opportunities and the balanced development of unit school and regional education. In order to make full use of the equality of educational opportunities, the effective countermeasure is the policy of educational finance, more specifically, the policy of educational expenses burden or the reasonable policy of educational finance distribution.

The gap of per capita education expenses is related to the gap of educational achievements as input conditions. The difference of educational finance invested in students leads to the difference of educational productivity between schools and regions. The fairness and efficiency of educational finance distribution is considered to be an important issue of education.

In order to achieve substantial equality through these minimum education expenses, the object of analysis should become the basic unit of educational activities and the student whose education finance is ultimately used. Therefore, students' education investment should be given priority. If the scale of financial support for education is close to the required level, it will not only be an important variable.

The necessity of this study is as follows. First, so far, there are too few financial researches on education, and there is no fair analysis of the per capita investment of students. From the perspective of the previous research on the financial fairness of pre education, the analysis object has limitations. So far, the research on the fairness of education finance has been concerned with the fairness in the level of city and Taoism Education Hall.

These studies mainly focus on whether the central government allocates education finance equally to the municipal and Taoist education departments. But the problem is that the central government allocates education finance to the city, the road and the land hall fairly, but this can not guarantee the fairness of the individual level of the unit schools. From this point of view, it is necessary to study the fairness analysis of students.

Secondly, it is necessary to analyze the fairness difference of the per capita investment of students in different regions. The first research is the analysis of the distribution of financial resources centered on the central government, local autonomous groups and local educational organizations, and the lack of analysis on the financial fairness of education between the municipal and the Daoists. Therefore, we should understand the equity difference of the investment in education of the student party among the education departments in different regions.

Moreover, we should understand the situation of the areas with high fairness and put forward countermeasures to the areas with low fairness.

Third, in the research of educational finance fairness, it is necessary to analyze how fair the financial resources students invest. Specifically, it is necessary to analyze the fairness level of the per capita labor cost and the investment amount of the student per capita facilities fee in each region. It is necessary to study whether the distribution level of labor cost and facility cost for the final beneficiaries of educational financial use and direct education activities is appropriate.

Therefore, this study will reveal the equity of the investment amount of the students in all cities and Taoism, and propose improvement plans. In the education finance, one of the parts that many scholars are concerned about and constantly debated is how much finance is needed to achieve the successful education results. The level of equity of investment in education fee is an important factor in successful education achievement[1].

It is very meaningful to analyze the financial fairness of education for students. After the diagnosis of the fairness of the current investment amount of students among regions, the reasonable improvement plan of education finance is provided to the relatively low areas, and the direction of the distribution and development of student education finance in the future is put forward. 


\section{RESEARCH QUESTIONS}

First, what is the fairness level of the per capita investment of students in different regions?

Second, according to different regions, what is the fairness level of students' per capita labor cost and facility cost investment?

\section{Literature REVIEW}

\section{A. Education expenses and investment per student}

At present, the original price of per capita tuition, which simply divides the per capita education fee into "all students in school", is open to the public [2]. The data of per capita education investment fee of students does not provide any preferential information for information users to make decisions.

The purpose of publishing students' investment expenses is to make use of students and parents as the demanders of education services to maximize the effect of their own investment expenses. Therefore, in order to improve the purposeful synthesis of information, we need to improve the current student party education fee standard.

There are not too many researches on per capita education expenses of students, and there are differences in the research on per capita education expenses of students according to the direction, purpose, use of research results, analysis methods and standards of education expenses.

From the perspective of previous studies, core education services and additional services in terms of the content of OECD support education fees, the per capita education fees of students are divided into the fees required for core services and the fees required for additional services.

In here "with the expansion of universal education welfare, the change and improvement program of education financial structure", most of the people who are equivalent to the school-age population receive education at free or low cost in school[5].

Compared with the total amount of education expenses, the investment of "per student education expenses" on the quality of education Because it is the variable of endorsement, it is of great significance. At the same time, comparing the changes of the composition of education fees for core education services and additional services with OECD, the following suggestions are put forward.

\section{METHODS}

The purpose of this study is to analyze the equity of investment in different regions, taking the per capita investment, the investment in labor cost and the per capita facility cost of students as the objects. In order to achieve this research goal, the annual trend of the per capita investment of " Local
Education Finance" students in local education finance will be used to analyze.

There are many methods to measure the financial fairness of education. This study mainly measures the level fairness. The level equity is measured by the single variable such as the per capita investment of students. In distribution, all students are allocated equal education expenses, which ensures the complete fairness.

The statistical method to measure the level fairness is to use the range, average value and Guinness coefficient to analyze the fairness level of the per capita investment of students according to the region. Gini coefficient mainly uses the cardinal number evaluation method to express the degree of imbalance with specific values [3].

Gini coefficient refers to the proportion of the area of Lorentz curve under the diagonal in the total area of the diagonal triangle. The closer the Gini coefficient is to 0 , there is no absolute criterion except for equality. Judging from the Gini coefficient checked in the first study, it is the same as Table 1.

Table 1. Guinness Coefficient Fairness SCORE EVALUATION STANDARD

\begin{tabular}{l|c|l|c}
\hline Classification & Fair & $\begin{array}{c}\text { Intermediate } \\
\text { State }\end{array}$ & $\begin{array}{c}\text { Not } \\
\text { Fair }\end{array}$ \\
\hline \hline $\begin{array}{l}\text { Odden\& } \\
\text { Picus[3] }\end{array}$ & $<0.4$ & $0.4 \sim 0.5$ & 0.5 \\
\hline $\begin{array}{l}\text { Jin } \\
\text { Nanshan[9] }\end{array}$ & $<0.3$ & - & 0.2 \\
\hline $\begin{array}{l}\text { Yin } \\
\text { Hongzhu[4] }\end{array}$ & $0.0 \sim 0.2$ & $0.2 \sim 0.4$ & 0.3 \\
\hline $\begin{array}{l}\text { Wu } \\
\text { fanhao[10] }\end{array}$ & $<0.2$ & $0.2 \sim 0.4$ & 0.4 \\
\hline This study & $0.0 \sim 0.2$ & $0.2 \sim 0.4$ & 0.4 \\
\hline
\end{tabular}

\section{RESUlts}

This chapter will compare and analyze the equity of the per capita investment, the per capita labor cost investment and the per capita facilities investment of students, and analyze the equity differences of the educational investment in different regions. In addition, the paper analyzes the changes of the per capita investment of students in different regions (2011-2014), and evaluates the fairness of the investment in the per capita labor cost and facilities cost.

The results of this study are as follows. First, the paper puts forward the analysis results of the equity level of the per capita investment of students in each region. Secondly, according to the different regions, what is the difference between the fairness of the investment of the per capita labor cost and the 
facility cost of the students.

\section{A. Equity of per capita investment of students in different regions}

From 2011 to 2014, the per capita investment cost of students in the municipal education departments has changed. The average per capita investment cost of students increased from 5.7468 million won in 2011 to 11.213 million won in 2014, gradually increasing with the year. The range also increased from 1.016 million won to 30.496 million won in 2014.

The Gini coefficient in 2011 and 2012 is 0.0016 and 0.0038 respectively, so the level fairness between regions is well observed. In 2013 and 2014, the price is 0.278 and 0.2958 respectively, so the level fairness between regions is somewhat unequal. On the whole, the fairness of per capita investment of each student in the Municipal Department of education shows a downward trend with the year.

Specifically, in 2011, the city with the largest per capita investment of students from the Municipal Department of education was Pusan 6.3 million won, the city with the lowest was Seoul special city, and Pusan, Incheon, and Guangzhou cities exceeded the average. In 2012, Busan, the city with the largest per capita student investment, was 6.992 million won, while Seoul, the city with the lowest per capita student investment, was 5.94 million won.

Busan, Yushan and Shizong are the areas that exceed the average level. In 2013, the city with the largest amount of investment per student was Shizong city with KRW 24.917 million, and the city with the lowest amount of investment was Incheon city with KRW 6.479 million. The area above the average is Shizong city. In 2014, the city with the largest amount of investment per student was Sejong city with 37.166 million won, and the city with the lowest amount was Seoul city with 6.67 million won. The area above the average is Shizong city.

\section{B. Equity of Education Finance}

Fairness means justice or fairness in the distribution of wealth, service or burden [7]. The related concept is equality, which mainly focuses on the quantity difference between groups, while fairness focuses on the quantity difference and quality difference. Fairness is also called fairness, fairness and equality [6].

Education finance regards fairness as the distribution of educational input, process and result, and is interested in the distribution of educational personnel, which embodies the realization of this policy [4]. Although there are many definitions of equity in education finance, the core contents can be summarized as horizontal equity, vertical equity and financial neutrality[3][8].

TABLE 2. ANNUAL CHANGE OF PER CAPITA INVESTMENT BY Municipal DePARTMENT OF EdUCATION (2011-2014) UNIT: $10000 \mathrm{WON}$

\begin{tabular}{|c|c|c|c|c|}
\hline City & 2011 & 2012 & 2013 & 2014 \\
\hline $\begin{array}{l}\text { Seoul } \\
\text { Special city }\end{array}$ & 528.4 & 594 & 653.1 & 667 \\
\hline Busan City & 630 & 699.2 & 754.2 & 810.1 \\
\hline Daegu City & 556.7 & 627.2 & 667.2 & 758.9 \\
\hline $\begin{array}{l}\text { Incheon } \\
\text { City }\end{array}$ & 603.9 & 605.7 & 647.9 & 731 \\
\hline $\begin{array}{l}\text { Datian } \\
\text { Wanan } \\
\text { City }\end{array}$ & 562.8 & 632.5 & 654 & 713.4 \\
\hline $\begin{array}{l}\text { Yushan } \\
\text { City }\end{array}$ & 556.8 & 653.7 & 743.5 & 820.5 \\
\hline $\begin{array}{l}\text { Guangzhou } \\
\text { Wanan } \\
\text { City }\end{array}$ & 584.2 & 610.8 & 669.4 & 751.6 \\
\hline Sejong & - & 663.7 & 2491.7 & 3716.6 \\
\hline Maximum & 630 & 699.2 & 2491.7 & 3716.6 \\
\hline Minimum & 528.4 & 594 & 647.9 & 667 \\
\hline $\begin{array}{l}\mathrm{N} / \mathrm{A} . \\
\text { range }\end{array}$ & 101.6 & 105.2 & 1843.8 & 3049.6 \\
\hline Average & 574.68 & 635.85 & 910.12 & 1121.13 \\
\hline $\begin{array}{l}\text { Gini } \\
\text { Coefficient }\end{array}$ & 0.0016 & 0.0038 & 0.2178 & 0.2958 \\
\hline
\end{tabular}

The results of the analysis of the per capita investment of students in each Taoist education department are as follows: Table 2. Overall, the average value of per capita investment of students has increased from 7.7116 million won in 2011 to 10.1945 million won in 2014. Specifically, in 2011, the per capita investment cost of students in Gyeonggi was 5.071 million won, the lowest, and the total South Road was 94,4300 won, with the highest investment amount. The average investment fee of six education departments, including JiangYuanDao, Zhongqing South Road, quanluo North Road, quanluo South Road, Qingshang North Road and jezhou Island, exceeded the average investment cost level, and the remaining three education departments did not reach the average investment cost. In 2012, the total South Road was the largest with 1.799 million won, and the capital road was 5.544 million won, with the least investment, which was the opposite compared with 2011. In 2013 and 2014, the most expensive area for each student is quanluonandao and the least is Jingji road.

The range from 2011 to 2014 has risen from 4.372 million won to 6.843 million won in 2014. The Gini coefficient was 0.0196 in 2011.0171, 2012, 0.01682 , 
2013, 0.0156 decreased gradually, and the investment cost of education among regions gradually became fair. 2014 was the fairest at 0.0156 .

TABLE 3. ANNUAL CHANGE OF PER CAPITA INVESTMENT OF STUDENTS IN DIFFERENT REGIONS UNIT: 10000 WON

\begin{tabular}{|c|c|c|c|c|}
\hline City & 2011 & 2012 & 2013 & 2014 \\
\hline $\begin{array}{l}\text { Gyeonggi } \\
\text { do }\end{array}$ & 507.1 & 554.4 & 599.4 & 669.1 \\
\hline $\begin{array}{l}\text { Jiangyuan } \\
\text { Road }\end{array}$ & 903.4 & 1008.3 & 1096.5 & 1170.7 \\
\hline $\begin{array}{l}\text { Zhongqing } \\
\text { North Road }\end{array}$ & 758.2 & 848.6 & 971.6 & 1044.8 \\
\hline $\begin{array}{l}\text { Zhongqing } \\
\text { South Road }\end{array}$ & 774 & 857.1 & 893.5 & 971.1 \\
\hline $\begin{array}{l}\text { Quanluo } \\
\text { North Road }\end{array}$ & 815.5 & 909.5 & 963 & 1045.5 \\
\hline $\begin{array}{l}\text { Quanluonn } \\
\text { Road }\end{array}$ & 944.3 & 1077.9 & 1174.3 & 1353.4 \\
\hline $\begin{array}{l}\text { Qingshang } \\
\text { North Road }\end{array}$ & 811.3 & 887 & 963.5 & 1053.2 \\
\hline $\begin{array}{l}\text { Qingshang } \\
\text { South Road }\end{array}$ & 636.1 & 738.5 & 794.5 & 881.1 \\
\hline Chejudo & 790.6 & 829.3 & 917.4 & 945.7 \\
\hline Maximum & 944.3 & 1077.9 & 1174.3 & 1353.4 \\
\hline Minimum & 507.1 & 554.4 & 599.4 & 669.1 \\
\hline $\mathrm{N} / \mathrm{A}$. range & 437.2 & 523.5 & 574.9 & 684.3 \\
\hline Average & 771.16 & 856.73 & 930.41 & 1014.95 \\
\hline $\begin{array}{l}\text { Gini } \\
\text { Coefficient }\end{array}$ & 0.0196 & 0.0171 & 0.0168 & 0.0156 \\
\hline
\end{tabular}

\section{Equity of labor cost investment per student in different regions}

From 2011 to 2014, the investment amount of labor cost per student of each Municipal Education Department has changed. The average amount of labor cost investment per student increased from 3.4202 million won in 2011 to 4.7893 million won in 2014 , gradually increasing with the year.

The range also increased significantly from 72,3000 won to 325,1000 won in 2014. The Gini coefficient was 0 in 2011 and 2012, and the level of fairness was very good. In 2013 and 2014, the Gini coefficients were 0.0465 and 0.1888 , which were relatively fair among regions.

Specifically, in 2011, Busan had the largest amount of per capita labor cost investment, while Guangzhou had the lowest amount of per capita labor cost investment, and Busan, Incheon and Yushan had the highest amount of per capita labor cost investment. In 2012, Busan, the city with the largest investment per student, was 4.291 million won, while Shizong, the city with the lowest, was 3.308 million won.

Busan, Incheon, Datian and Yushan are the areas above the average. In 2013, the city with the largest labor cost investment per student was Sejong city with 6.365 million won, and the city with the lowest labor cost investment was Guangzhou city with 3.9 million won. Busan and Shizong are the areas that exceed the average level. In 2014, the city with the largest labor cost investment per student was Sejong city of 7.444 million won, and the city with the lowest labor cost investment was Seoul city of 4.193 million won. Busan and Shizong are the areas that exceed the average level.

\section{Conclusion}

This study analyzes the equity of the per capita investment scale of students. According to the research results of this study, the conclusions are as follows.

First, on the whole, the per capita investment of students in the city, the road and the land department is relatively fair. The per capita investment of students in different regions of the Municipal Department of education was unequal from 2012 to 2014. The average amount of investment per student keeps a level fairness among different Taoist education departments. Specifically, the Gini coefficient of per capita investment of each city's Department of education was 0.0016 in 2011, 0.0038 in 2012, 0.278 in 2013 and 0.295 in 2014, showing a gradually increasing trend from 2012 to 2014 .

The Gini coefficient of per capita investment of Taoist Education Department decreased from 0.0196 in 2011 to 0.0156 in 2014. Second, according to different regions, the fairness of the investment amount of labor cost and facility cost per student is different. It can be seen that the investment amount of labor cost per student is fair among city, road and land departments.

From the Gini coefficient of the Municipal Department of education, it shows a gradual upward trend from 2011 to 2014, but the per capita labor cost investment of the Municipal Department of education is relatively fair. From the Gini coefficient of Taoist education department between regions, it shows a gradual downward trend from 2011 to 2014, but the per capita labor cost investment of students is gradually fair.

\section{REFERENCES}

[1] Mun, S.B.(2012). An Analysis of Equity in Korean Education Based on OECD International Indicators: Focusing on Comparisons between Cities and Provinces, Korean Educational Development Institute. 
[2] Wu Zhenying. (2011). Research on reasonable calculation scheme of per capita education expenses of students. Master's thesis.Myongyi University.

[3] Odden, A. R. \&picus, L. O. (2007). School Fiance: A Policy Perspective (4thed.). NY: McGraw-Hill.

[4] Yin Hongzhu. (2004). Analysis on the equity of Education Finance: focusing on the unit school finance. Doctoral dissertation. Seoul University.

[5] An Zhongshuo. (2014). With the expansion of universal education welfare, the financial structure of education has changed and improved. Local education finance policy forum, local education finance research center of Korea Institute of education and development.

[6] Pan sunjin.(2014). Education finance. Seoul: Study group .

[7] Yin zhengri (2004). On the school of education and finance. Seoul: Shiying Temple.

[8] Zhou zhe'an.(1992).Research on the concept and measurement methodology of educational finance fairness. Research on education finance and economy, 25, 85-99.

[9] Jin Nanshan. (1997). Research on the operation of comprehensive school system in agricultural and fishing villages. Sociology of education research, 7(1), 25-55.

[10] Wu fanhao. (2014). An analysis of the equity of special education finance, Primary education in Korea, .25(4), 185200. 